\title{
İyi Huylu Böbrek Tümörlerinde Medikal Tedavi
}

\author{
Çağdaş Şenel ${ }^{1}$, Ahmet Asfuroğlu², Altuğ Tuncel ${ }^{2}$
}

${ }^{1}$ Kahta Devlet Hastanesi, Üroloji Kliniği, Adıyaman

${ }^{2}$ Sağlık Bilimleri Üniversitesi, Ankara Numune Sağlık Uygulama ve Araştırma Merkezi, Üroloji Kliniği, Ankara

\section{Özet}

Anjiyomiyolipoma en sık görülen iyi huylu böbrek tümörlerinden biridir. Anjiyomiyolipoma'ların yaklaşık \%20'si genetik bir hastalık olan tuberoskleroz ile birlikte görülmektedir. Tuberoskleroz'un genetik ve moleküler yolaklarının anlaşılması mammalian target of rapamycin inhibitörlerinin tuberoskleroz ilişkili anjiyomiyolipoma tedavisinde kullanımını gündeme getirmiştir. Mammalian target of rapamycin inhibitörlerinin anjiyomiyolipoma tedavisinde kullanımı ile ilgili yapılan çalışmalarda olumlu sonuçlar elde edilmektedir. Bu derlemede iyi huylu böbrek tümörlerinde medikal tedavinin kullanımı uluslararası güncel literatür ışı̆̆ında okuyucular ile paylaşılacaktır.

Anahtar Kelimeler: anjiyomiyolipoma, everolimus, sirolimus, tedavi

\section{Giriş}

G ünümüzde görüntüleme yöntemlerinin yaygın kullaJnımı ile böbrek kitlelerinin saptanma oranı artmıştır $(1,2)$. Böbrek kitlelerinin yaklaşık \%20'si iyi huylu böbrek tümörleridir (3). İyi huylu böbrek tümörlerinin ise \%37'sinianjiyomyolipoma (AML) oluşturmaktadır (4). AML sıklıkla sporadik olarak görülmekte olup AML olgularının \%20'si tuberoskleroz kompleksi (TSK) ve lenfanjiyomiyomatozis (LAM) ile birlikte bulunmaktadır (5). TSK ve LAM'ın patogenezinde; mammaliantarget of rapamycin (mTOR) yolağının düzenlenmesinde görevli olan TSK genlerindeki heterozigosite kaybı bulunmaktadır $(6,7)$. Son yıllarda medikal tedavi, artan genetik ve moleküler temelli çalışmaların da yardımı ile cerrahi ve minimal invaziv girişimler ile birlikte iyi huylu böbrek tümörlerinin tedavisinde kabul görmeye başlamıştır. Günümüzde medikal tedavi iyi huylu böbrek tümörleri içerisinde AML tedavisinde kendisine yer bulmuş olup bu amaç ile mTOR inhibitörleri kullanılmaktadır. Bu derlemede iyi huylu böbrek tümörlerinde medikal tedavinin kullanımı uluslararası güncel literatür ışı̆̆ında okuyucular ile paylaşılacaktır.

AML

AML; patolojik olarak iyi huylu, vasküler, düz kas ve yağ dokuları içeren nadir görülen mezenkimal bir böbrek tümörüdür (8). AML olgularının büyük çoğunluğu sporadik iken yaklaşık \%23'ü TSK ile ilişkilidir (9).

Renal AML, TSK ve LAM'ın en önemli klinik özelliklerindendir. TSK olgularının \%80'inde renal AML görülmektedir. TSK varlığında renal AML daha genç yaşlarda bilateral, çok sayıda ve daha büyük boyutlarda ortaya çıkmaktadır. Sporadik vakalarda ise unilateral, tek odaklı ve daha küçük boyutlu renal AML tespit edilmektedir (7).
TSK sistemik bir hastalık olup ve otozomal dominant geçişlidir. Tüm dünyada insidansı 1/6.000-10.000 arasında değişmekle birlikte dünya çapında 2.000 .000 kişiyi etkilediği öngörülmektedir (6). AML'nin dişında santral sinir sisteminde, ciltte ve diğer organlarda görülen hamartomlar TSK'nın klinik özelliklerindendir (10).

TSK'nın oluşumunda; otozomal dominant geçiş gösteren mTOR yolağının düzenlenmesinde görevli tümör baskılayıcı genler olan TSK-1 ve TSK-2 genlerindeki heterozigosite kaybı rol oynamaktadir. Bu durum AML, LAM, subependimal dev hücreli astrositom, kardiyak sarkom gibi farklı organlarda tümör gelişimine yol açmaktadır $(6,7)$. LAM, ilerleyici ve mortalite oranları yüksek bir interstisyel akciğer hastalığı olup çoğunlukla düz kasların anormal diffüz proliferasyonu ile karakterizedir. LAM, sıklıkla TSK içerisinde karşılaşılmasına rağmen sporadikolarak da görülebilmektedir (11). AML, sporadik LAM olgularının \%32'sinde görülür iken bu oran TSK ilişkili LAM'da \%93'e çıkmaktadır (12). LAM tanılı hastaların genetik incelemelerinde ise sıklıkla TSK-2 geninde heterozigosite kaybı karşımıza çıkmaktadır (13).

AML yavaş seyirli bir büyüme hızına sahip olup sıklıkla asemptomatiktir $(14,15)$. Semptomatik AML olgularında ise en önemli başvuru semptomları kanama ve tümör rüptürüne bağlı gelişen ağrı ile hipovolemik şoktur. AML'nin en ciddi semptomu olan kanamanın riski, kitle çapı $>4 \mathrm{~cm}$ ve anevrizma çapı $>5 \mathrm{~mm}$ olan lezyonlarda artmaktadır (16). AML'de kanama riskinin nedeni normal olmayan, elastinden fakir vasküler yapıların varlığıdır (17).

AML olgularında hastanın kesin tedavi şansını kaybetmemesi koşulu ile aktif izlem günümüzde en çok tercih edilen seçenektir. Tedavi seçenekleri ise selektif arteriyel embolizasyon, radyofrekans ablasyon, parsiyel veya radikal nefrektomi ile medikal tedavidir (18). Avrupa Üroloji Kılavuzu'nun 2017 yılı basımında; büyük tümöre sahip hastaların, gebelik çağındaki kadınların, takip edilmesi veya acil 
durumlarda sağlık kurumlarına ulaşımı zor olan hastaların selektif arteriyel embolizasyon ya da nefron koruyucu cerrahi ile tedavi edilmesi önerilmektedir (19).

\section{Medikal Tedavi}

Tuberoskleroz'da TSK-1 ve TSK-2 genlerinin kaybı hücre büyümesi, anjiyogenezis ve proliferasyonunun düzenlenmesinde görev alan bir kinaz olan mTOR'un aşırı aktivasyonuna neden olarak iyi huylu tümörlerin gelişimine yol açar (20).

Günümüzde genetik yolakların ve ilişkilerin daha iyi anlaşılması TSK ya da LAM ile ilişkili renal AML'nin tedavisinde mTOR inhibitörlerinin kullanımını gündeme getirmiştir. Medikal tedavinin amacl; tümör hücrelerinin progresyonunu engellemek ve tümör boyutunu azaltmaktır. Renal AML'nin medical tedavisinde ilk kullanılan mTOR inhibitörü sirolimus olup halen AML tedavisinde onaylanmiş tek mTOR inhibitörü everolimus'tur.

Bissler ve ark. 2008 yılında sirolimus'un TSK veya LAM ile ilişkili AML'deki etkinliğini incelemiştir. Bu çalışmaya dahil edilen 25 hasta, 12 aylık sirolimus tedavisinden sonra görüntüleme yöntemleri ile takibe alınmışlardır. Çalışmanın sonucunda sirolimus tedavisi süresince AML boyutunda anlamlı azalma görülür iken $(\mathrm{p}<0.001)$ tedavi bitiminden sonraki takip döneminde tümör boyutunda artış eğilimi saptanmıştır. Ayrıca 5 hastada diyare, piyelonefrit, stomatit ve solunum yolu enfeksiyonu gibi ciddi yan etkiler gelişmiştir. Yazarlar mTOR yolağının baskılanması ile TSK veya sporadik LAM tedavisinde başarı sağlanabileceği sonucuna varmışlardır (21).

Davies ve ark. tarafından yayınlanan çok merkezli faz 2 çalışmada 16 TSK ve/veya sporadik LAM tanılı hastaya sirolimus tedavisi başlanmış ve hastalar takibe alınmıştır. Tedaviye genel yanıt oranı Solid Tümörlerde Yanit Değerlendirme Kriterleri (RECIST)'ne göre \%50 (8/16) olarak bulunmuştur. Toplam 48 AML lezyonunun $41^{\prime}$ inde tedavi başlangıcina göre tümör boyutunda azalma, 5 'inde artma saptanır iken 2 lezyonun boyutunda değişme gözlenmemiştir. Tümör boyutundaki ortalama küçülme ilk 12 ay için 7.3 $\mathrm{mm}$ saptanır iken sonraki 12 ayda bu küçülme $0.7 \mathrm{~mm}$ olarak bulunmuştur. Çalışma boyunca en sık görülen yan etkiler oral mukozit $(n=6)$, solunum yolu enfeksiyonları $(n=5)$ ve proteinüri $(\mathrm{n}=5)$ olarak belirtilmiştir (22).

Sirolimus (rapamisin) tedavisinin incelendiği bir başka çalışmaya TS tanılı 17 hasta dahil edilmiştir. On iki aylık tedavinin sonrasında AML boyutlarındaki ortalama azalma \%66.3 olarak bulunur iken 14 hastanın (\%82.4) tümör boyutunda en az $\% 50$ oraninda azalma saptanmıştır. En sik görülen yan etki 5 hastada görülen aftöz oral ülser olarak belirtilmiştir. Çalışmanın sonucunda yazarlar sirolimus'un TS tedavisinde etkili bir rol oynayabileceği sonucuna varmışlardır (23). Aynı hasta grubunun 24 aylık takip sonuçlarının bildirildiği çalışmada ise hastaların 24. ay takiplerinde 10 hastanın (\%58.8) tümör boyutunda en az \%50 oraninda azalma saptanmıştır. Bu çalışmada tümör boyutundaki azalmanın ilk 12 ay daha belirgin olduğu belirtilir iken tümör boyutundaki azalmanin 12. ve 24. aylar arasında farklı olmadığı bulunmuştur (24).

Bissler ve ark. nın, 2013 yılında yayınladıkları 118 hastayı içeren çok merkezli faz 3 çalışmada everolimus tedavisi $(n=79)$ plasebo $(n=39)$ ile karşılaştııılmıştır. Everolimus gru- bunda ortalama yanit oranı $\% 42$ olarak bulunur iken plasebo grubunda bu oran $\% 0$ olarak bildirilmiştir. Everolimus tedavisine ortalama yanıt süresi 2.9 ay bulunmuştur. Hastaların 24. hafta takiplerinin sonucunda; AML hacminde en az $\% 50$ azalma everolimus grubunun $\% 55^{\prime}$ inde $(n=39)$, en az $\% 30$ azalma ise \%80'inde $(\mathrm{n}=57)$ sağlanmıştır. Everolimus tedavisi alan 4, plasebo alan 8 hastada AML hacminde progresyon saptanmıştır. Everolimus grubunda en sık görülen yan etkiler stomatit (\%48), nazofarenjit (\%24) ve akne benzeri cilt lezyonları (\%22) olarak bildirilmiştir. Çalışmanın yazarları everolimus'un AML hacmini kabul edilebilir güvenlik sınırlarında azalttığ ve TSK ile ilişkili AML'nin tedavisi olabileceği sonucuna varmışlardır (25).

Robles ve ark. 19 hastada TSK ilişkili AML tedavisinde everolimus'un güvenlik ve etkinliğini incelemiştir. Bu çalışmada 9 hastanın (\%47.4) tümör boyutu >\%50 azalırken 11 hastanın (\%57.9) tümör boyutu $>\% 30$ oranında azalma göstermiştir. Sadece 1 hastada ciddi yan etki (pnömoni) görülür iken yan etki nedeni ile 8 hastanın tedavi dozu değiştirilmiş ya da tedaviye geçici olarak ara verilmiştir. Yazarlar çalışmanın sonucunda elde edilen verilerin renal AML'de everolimus tedavisinin faydalı olduğunu desteklediğini bildirmişlerdir (26).

Hatano ve ark. renal AML'de everolimus'un etkinliğini inceledikleri çalışmasında 47 olgunun 46'sında tümör boyutunda azalma saptandığını ve 12 ay sonunda ortalama azalmanın \%60 olduğunu rapor etmiştir. Çalışmada en sık görülen yan etkilerin stomatit (\%91) ve düzensiz menstruasyon (\%65) olduğu ve ilk 6 aylık sürede tüm hastalarda yan etki görüldüğü bildirilmiştir (27).

Everolimus ile yapılan başka bir çalışmada ise $2.5 \mathrm{mg} /$ gün ve $5 \mathrm{mg} /$ gün dozları karşılaştırılmıştır. Tümör boyutundaki azalma $5 \mathrm{mg} /$ gün everolimus tedavisi alan hastalarda anlamlı olarak yüksek saptanmışır (28). (\%40.7-73.1 vs \%10.5-45.3, $\mathrm{p}<0.05)$

Coombs tarafından 2013 yılında yayınlanan derlemede mTOR inhibitörlerinin (sirolimus ve everolimus) renal AML tedavisindeki rolü incelenmiştir. Bu derlemede TSK ilişkili AML'de lezyonların bilateral ve çok sayıda olması nedeni ile cerrahi ve invaziv girişimsel işlemlerin uygun olmadığ 1 ve mTOR inhibitörlerinin AML boyutunu azaltarak hastalara büyük fayda sağladığı sonucuna varılmıştır (29).

Güncel başka bir derlemede ise mTOR inhibitörlerinin TSK ilişkili renal AML tedavisinde etkili olduğu ancak yapılacak çalışmalar ile optimal tedavi dozu ve süresinin belirlenmesi gerektiği vurgulanmıştır (30).

Flum ve ark. tarafından yayınlanan renal AML'nin tanı ve tedavisinin incelendiği derlemenin sonuç kısmında tedavi gereksinimi olan hastalarda nefron koruyucu cerrahi ve selektif arteriyel embolizasyonun tercih edilen seçenekler olduğu, mTOR inhibitörlerinin ise TSK ilişkili AML tedavisinde renal parankimi korurken tümör kontrolünü sağlaması nedeni ile uygun bir tedavi yöntemi olduğu belirtilmiştir (15).

Uluslararasi Tuberoskleroz Kompleksi Konsensusu (ITSCC)'nun 2012 yilındaki toplantısında; asemptomatik, 3 cm'den büyük çaptaki TSK ilişkili renal AML'nin 1. basamak tedavisinde mTOR inhibitörleri önerilmektedir (31).

Avrupa Üroloji Kılavuzu incelendiği zaman, cerrahi girişim gerektirmeyen $3 \mathrm{~cm}$ 'nin üzerindeki AML olgularında everolimus ile medikal tedavinin düşünülebileceği belirtilmiştir (19). 


\section{Sonuç}

Güncel literatür verileri incelendiğinde TSK ilişkili AML hastalarında mTOR inhibitörlerinin kullanımı; invaziv bir girişim olmaması ve tümör hacminde anlamlı azalma sağlaması nedeni ile umut vermektedir. Ancak bu tedavinin yan etki sıklığı, tedavi bitiminde tümör boyutlarında artış görülebilmesi tedavi ile ilgili dikkate alınması gereken konulardır. AML'nin medikal tedavisinde mTOR inhibitörlerinin rutin klinik uygulamada yer alabilmesi için geniş serili, uzun takip süreli çalışmalara ihtiyaç duyulmaktadır.

\section{Kaynaklar}

1. Murphy AM, Buck AM, Benson MC, McKiernan JM. Increasing detection rate of benign renal tumors: evaluation of factors predicting for benign tumor histologic features during past two decades. Urology 73:1293-1297,2009.

2. Simard EP, Ward EM, Siegel R, Jemal A. Cancers with increasing incidence trends in the United States: 1999 through 2008. CA Cancer J Clin62:118-128,2012.

3. Sriram R, Van Criekinge M, DeLosSantos J, Keshari KR, Wilson DM, Peehl D, et al. Non-invasive differentiation of benign renal tumors from clear cell renal cell carcinomas using clinically translatable hyperpolarized 13C pyruvate magnetic resonance. Tomography 2: 35-42,2016.

4. Mauermann J, de Martino M, Waldert M, Haitel A, Klingler HC, Remzi $M$, et al. Gender differences in benign renal masses. World J Urol31:1051-1057,2013.

5. Bissler JJ, Kingswood JC. Renal angiomyolipomata. Kidney Int 66:924-934,2004.

6. Sancak O, Nellist M, Goedbloed M, Elfferich P, Wouters C, Maat-Kievit A, et al. Mutational analysis of the TSC1 and TSC2 genes in a diagnostic setting: genotypephenotype correlations and comparison of diagnostic DNA techniques in Tuberous Sclerosis Complex. Eur J Hum Genet 13:731-741,2005.

7. Liang S, Cuevas G, Tizani S, Salas T, Liu H, Li B, et al. Novel mechanism of regulation of fibrosis in kidney tumor with tuberous sclerosis. Mol Cancer 12:49,2013.

8. Giannikou K, Malinowska IA, Pugh TJ, Yan R, Tseng YY, $\mathrm{Oh} \mathrm{C}$, et al. Whole exome sequencing identifies TSC1/ TSC2 biallelic loss as the primary and sufficient driver event for renal angiomyolipoma development. PLoS Genet 12:e1006242,2016.

9. Seyam RM, Bissada NK, Kattan SA, Mokhtar AA, Aslam $\mathrm{M}$, Fahmy WE, et al. Changing trends in presentation, diagnosis and management of renal angiomyolipoma: comparison of sporadic and tuberous sclerosis complexassociated forms. Urology 72:1077-1082,2008.

10. Bjornsson J, Short MP, Kwiatkowski DJ, Henske EP. Tuberous sclerosis-associated renal cell carcinoma. Clinical, pathological, and genetic features. Am J Pathol 149:1201-1208,1996.

11. Johnson SR, Cordier JF, Lazor R, Cottin V, Costabel U, Harari S, et al. European Respiratory Society guidelines for the diagnosisand management of lymphangioleiomyomatosis. Eur Respir J 35:14-26,2010.

12. Curatolo P, Bombardieri R, Jozwiak S. Tuberoussclerosis. Lancet 372:657-668,2008.
13. Carsillo T, Astrinidis A, Henske EP. Mutations in the tuberous sclerosis complex gene TSC2 are a cause of sporadic pulmonary lymphangioleiomyomatosis. Proc Natl Acad Sci U S A 97:6085-6090,2000.

14. Mues AC, Palacios JM, Haramis G, Casazza C, Badani $\mathrm{K}$, Gupta $\mathrm{M}$, et al. Contemporary experience in the management of angiomyolipoma. J Endourol 24:18831886,2010 .

15. Flum AS, Hamoui N, Said MA, Yang XJ, Casalino DD, McGuire BB, et al. Update on the diagnosis and management of renal angiomyolipoma. J Urol 195:834-846,2016.

16. Yamakado K, Tanaka N, Nakagawa T, Kobayashi S, Yanagawa M, Takeda K. Renal angiomyolipoma: relationships between tumor size, aneurysm formation, and rupture. Radiology225:78-82,2002.

17. Eble JN. Angiomyolipoma of kidney. Semin DiagnPathol 15:21-40,1998.

18. Ouzaid I, Autorino R, Fatica R, Herts BR, McLennan $\mathrm{G}$, Remer EM, et al. Active surveillance for renal angiomyolipoma: outcomes and factors predictive of delayed intervention. BJU Int 114:412-417,2014.

19. Ljungberg B, Albiges L, Bensalah K, Bex A, Giles RH, Hora M, et al. EAU Guidelines on Renal Cell Carcinoma, 2017. Available at: http://uroweb.org/guideline/renalcell-carcinoma.

20. Franz DN, Belousova E, Sparagana S, Bebin EM, Frost MD, Kuperman R, et al. Long-term use of everolimus in patients with tuberous sclerosis complex: final results from the EXIST-1 study. PLoS One 11:e0158476,2016.

21. Bissler JJ, McCormack FX, Young LR, Elwing JM, Chuck G, Leonard JM, et al. Sirolimus for angiomyolipoma in tuberous sclerosis complex or lymphangioleiomyomatosis. N Engl J Med 358:140-151,2008.

22. Davies DM, de Vries PJ, Johnson SR, McCartney DL, Cox JA, Serra AL, et al. Sirolimus therapy for angiomyolipoma in tuberous sclerosis and sporadic lymphangioleiomyomatosis: a phase 2 trial. Clin Cancer Res 17:4071-4081,2011.

23. Cabrera López C, Martí T, Catalá V, Torres F, Mateu $\mathrm{S}$, BallarínCastán $\mathrm{J}$, et al. Effects of rapamycin on angiomyolipomas in patients with tuberous sclerosis. Nefrologia 31:292-298,2011.

24. Cabrera-López C, Martí T, Catalá V, Torres F, Mateu S, Ballarín J, et al. Assessingtheeffectiveness of rapamycin on angiomyolipoma in tuberous sclerosis: a two years trial. Orphanet J Rare Dis 7:87,2012.

25. Bissler JJ, Kingswood JC, Radzikowska E, Zonnenberg BA, Frost M, Belousova E, et al. Everolimus for angiomyolipoma associated with tuberous sclerosis complex or sporadic lymphangioleiomyomatosis (EXIST2): a multicentre, randomised, double-blind, placebocontrolled trial. Lancet 381:817-824,2013.

26. Robles NR, Peces R, Gómez-Ferrer Á, Villacampa F, Álvarez-Ossorio JL, Pérez-Segura P, et al. Everolimus safety and efficacy for renal angiomyolipomas associated with tuberous sclerosis complex: a Spanish expanded access trial. Orphanet J Rare Dis 11:128,2016.

27. Hatano T, Chikaraishi K, Inaba H, Endo K, Egawa S. Outcomes of everolimus treatment for renal angiomyolipoma associated with tuberous sclerosis complex: A single institution experience in Japan. Int J Urol 23:833-838,2016. 
28. Tsai JD, Wei CC, Yang SH, Fan HC, Hsu CC, Tung $\mathrm{MC}$, et al. The effects of everolimus on tuberous sclerosis complex-associated renal angiomyolipoma: a preliminary report. Nephrology (Carlton) 22: 1017-1022, 2017.

29. Coombs EJ. Role of mTOR inhibition in the treatment of patients with renal angiomyolipomas. J Am Assoc Nurse Pract 25:588-596,2013.

30. Curatolo P, Bjørnvold M, Dill PE, Ferreira JC, Feucht M, Hertzberg $\mathrm{C}$, et al. The role of mTOR inhibitors in the treatment of patients with tuberous sclerosis complex: Evidence-based and expert opinions. Drugs 76:551565,2016 .
31. Krueger DA, Northrup H; International Tuberous Sclerosis Complex Consensus Group. Tuberous sclerosis complex surveillance and management: recommendations of the 2012 International Tuberous Sclerosis Complex Consensus Conference. Pediatr Neurol 49:255-265,2013.

Yazışma Adresi:

Altuğ Tuncel,

Sağlık Bilimleri Üniversitesi Ankara Numune Ĕ̆itim ve Araştırma Hastanesi, Üroloji Klini ğgi, 06120, Sihhiye, Ankara

Tel: +903125085055

e-mail: tuncelaltug@yahoo.com 